\title{
Exchanges Create Relations
}

\begin{abstract}
There are numerous explanations for why we pay tax, an important aspect being the relations, and expectations, that taxpaying is seen to create. This chapter revisits various research traditions on tax compliance and proposes four different ways in which it addresses reciprocity: tit-fortat, copy-cat, fair share and equality. Sweden, a 'modern' welfare state, has a well-esteemed tax collecting agency that has worked long and deliberately to enhance its standing in society. Despite the agency being liked, tax avoidance is also going on. This ethnography travels full circle around seemingly opposing actors on the Swedish tax arena, at the Swedish Tax Agency and among a group of tax-avoiding Swedes, listening to their stories and justifications - allowing for a thorough understanding of reciprocal relations invoked by carrying out taxation.
\end{abstract}

Keywords Reciprocity in tax compliance research - Thinking with reciprocity $\bullet$ Ethnography of taxation and tax avoidance

Those who exchange presents with one another

Remain friends the longest

If things turn out successfully (Mauss 2002 [1990]: 2)

Thus ends the forty-first stanza in Hávamál, one of the many poems in the Scandinavian Edda.

(C) The Author(s) 2018

L. Björklund Larsen, A Fair Share of Tax, https://doi.org/10.1007/978-3-319-69772-7_1 
Friends certainly exchange presents, but they do so much more in order to remain friends; especially if they want to remain friends for a long, long time-perhaps even for life. This is also the case if we think more broadly about presents than the occasional birthday gift and the bottle of wine brought for dinner, and extend our thinking to friendship as a helping hand in need or a listening ear when there are things to tell. Yet then comes the third line- 'if things turn out successfully'. There are thus not only two 'friends' here, two people who exchange presents in the broadest sense possible, but an externality. Two people, even two friends, cannot exchange gifts in a vacuum. There are other things that can happen which have a potential impact on the relationship.

There is more about such relationships in Hávamál. The forty-sixth stanza ends with

Presents given in return must be similar to

Those received (ibid.)

Aha... we are looking for an equilibrium. There cannot be any old countergift, but it has to be similar to the initial gift. And finally, in the 145th stanza, we are reminded that exchanging gifts demands courtesy; there is even a hint towards modesty. Yet the reflections in Hávamál about exchanging gifts never lose their focus on balancing the relationship.

It is better not to beg [ask for something]

Than to sacrifice too much [to the gods]:

A present given always expects one in return.

It is better not to bring any offering

Than to spend too much on it (ibid.: $2-3$ ). ${ }^{1}$

Let the words linger. These poems were compiled and written down in the thirteenth century and they contain histories from the earliest of Viking times. The stories in the Edda are from a very different time; they are part mythology and part stories about values, beliefs and livelihoods. They are also the main source of what we know about Norse mythology. The Edda, a collection of sagas from medieval Iceland, provides some eternal truths, and this ancient poem in particular still speaks to us about how relations are created by exchanging things, telling us that such exchanges have to be carefully made if the relationship is to remain 'successful'. 
I use these stanzas to direct you in space and time; geographically to the north of the globe where Vikings resided, specifically to Sweden, and more specifically again to the country's contemporary tax collection system and the avoidance of such payments. The Edda lines about people exchanging and their resulting moral implication are also part of the introduction to the seminal book The Gift. Written by French sociologist Marcel Mauss and published in 1925, it is a slim book about the universal human capacity to give, to receive and to give again. It grants us examples from all over the world of how people make exchanges and the relations these exchanges create; how people reciprocate. It proposes that by exchanging, by offering a gift as it were, society is made possible. It suggests that to exchange 'things', and thus create relations, is an eternal human propensity. ${ }^{2}$

Yet The Gift is probably the most inappropriately named book in social science (Hart 2007) as it discusses so much more than the altruistic transfer of a good. Expanding the gift to a more ubiquitous exchange such as market transaction, trade, barter, swap, transfer and even theft can see such exchanges as creating some sort of relationship. And what if we think about taxes in those terms? As a type of exchange that also creates relationships?

Taxation is a hotly debated topic in most countries, and citizens all over the world pay - and avoid paying — various taxes and fees to their government. Taxes finance infrastructure, defence and welfare for the supposed benefit of all citizens. Most countries have an elaborate and organized tax structure to collect tax revenue and transfer it to institutions in order to pay for various public needs and government functions. As taxation is instituted by laws, failing to declare or to pay tax, as well as evading or resisting taxation, is usually also a punishable offence.

Citizens, therefore, are more or less forced to pay various taxes but also live in the society where the revenue is collected and allocated. ${ }^{3}$ This creates the expectation that they will get something back; but what will be given is the subject of much consideration and debate. Taxes and the collection of tax are in their broadest definition what politics is all about: who should pay, how much is needed, and how and on whom the state should spend the money that is collected from its citizens and other taxpayers. Yet this is not the primary issue at stake here-my focus is on the expectations that taxation create. Regardless of what we pay tax on, there is usually some sort of expectation that we will get something for the fees, taxes and excise paid to the governing body. If we give something, we also expect to 
get something back, regardless of whom we pay. To give something creates a relationship, and the focus in this book is on the relations that taxes and taxation, as a process of collecting revenue, create.

In this book I argue that in order to understand why we pay tax-that is, why we accept tax compliance-as well as why we avoid doing so, we have to look beyond legal changes, psychological experiments, economic results, the organization of revenue collection and all actors' practices in society's tax arena and study the type of relations, and expectations, that taxpaying is seen to create in society. In this quest, returning to Marcel Mauss and his analysis of the gift and its resulting relations will help us understand this. I want to direct our gaze onto the concept of reciprocity, which is often proposed as an explanation in tax compliance research, and explore its diverse meanings and implications.

First, taking reciprocity seriously means that we have to expand the view of reciprocity as a dyadic relation between two exchangers to include other citizens/members of society which in matters of taxation is often synonymous with the state. I shall argue that similar types of expectation to those that exist between exchangers reside in the relationship that citizens as taxpayers have with the state. Although exchanges between inhabitants and state are vast even from a daily perspective, impossible to quantify or account for, and immensely complicated in a welfare state, we will see that there is a residual sense of a reciprocal relationship. From a resident's perspective does thinking about taxes in reciprocal terms also make for demands on the state? Indeed, does paying taxes have an impact on one's expectations of what society should provide?

Second, thinking about taxation as giving something draws our attention to the balancing that goes on in society. Paying tax means creating and maintaining different types of societal relationship and acquiring an identity in such relationships; giving too much — or receiving too much for that matter-has, according to Mauss, implications for the status that one has in society. What is the impact of a given tax system, its redistributive effect and the resulting reciprocal relations it creates on one's societal status, one's group in society, and one's society vis-à-vis other societies?

Third, I will direct your attention to the actual giving and taking-and the order in which this comes - to explain how cheating by taxpayers can be justified and thus made legitimate (at least in their own eyes).

Viewing taxes as a citizen's explicit economic relation to the state and implicit relation to all other citizens brings us straight to the core of economic anthropology. Our focus thus changes from legal explanations and 
economic quantification to the type of reciprocal relations that taxes and tax collection entail. ${ }^{4}$ Fiscal anthropology starts out from this perspective and frames this book. With this approach, we explore the view of taxation as the citizen's relationship to the state and to all compatriots, based on ethnographic examples from Sweden. The book concludes by raising the gaze from Sweden in order to propose a number of considerations regarding reciprocity that societies have to deal with-if they are aiming to increase tax compliance.

'I tell you why I buy work off the books. This family has paid far too much to the state already,' says a former neighbour. I heard a number of people expressing themselves in similar terms when they were explaining why they, and other Swedes, engage in informal transactions. Expressed in those terms, can such purchases be seen as a response to a feeling of having contributed too much to the state? To regard taxation in a modern democracy such as Sweden from a relational point of view casts a more nuanced light on Swedes' propensity to cheat with taxes. Life is not so simple that their motives for purchasing informal work are purely economic, (im)moral or continue the way 'we have always exchanged', but it reflects the view that in the course of the day, we enter into an immensely wide array of exchange relationships, with complex relations between them' (Slater 2002: 237).

In the following you will get to know more about my former neighbour as well as many other Swedes. There are the Limningers, a group of middle-aged people who went to the same school as I did. You will learn about their explanations and justifications for complying with and avoiding taxation, focusing on the reciprocal aspects-there were many other types of justification (Björklund Larsen 2010). Limningers explain their different strategies and experiences of informal exchanges for avoiding tax, but also what makes them comply. Then there are the employees at the Swedish Tax Agency, hereafter referred to as the Agency. These analysts, managers, legal experts and tax collectors are more or less aware of citizens', such the Limningers', various justifications and strategies. We will thus also receive the collectors' perspective on what makes up the relatively high tax compliance that Swedish society is said to have; a level of compliance that is made possible by the Agency's careful and detailed handling of an all-encompassing tax law. This book thus goes full circle around the issue of Swedish taxation, listening to both tax collectors' and citizens' explanations in an ethnographic light. 
All informants' real names are anonymized. This was particularly important regarding the Limningers, who after all spoke about illegal exchanges. Any information about surroundings, life stories and family conditions has been slightly altered in order not to reveal any possible connections between statements and specific informants. Occupations have been changed as well, but to something with similar status in Swedish society as well as similar access to informal exchanges. All interviews with informants, both Limningers and those at the Agency, including the many meetings I attended at the Agency, have been transcribed word for word. In what follows, all informants' quotes are literal translations into English.

\section{DeFining TAXATION}

Taxation serves many purposes and the ingenuity in finding new ways to tax citizens is simply amazing. Probing into definitions of taxation tells us more about this variety. The Encyclopaedia Britannica states in its entry on taxation: 'imposition of compulsory levies on individuals or entities by governments. Taxes are levied in almost every nation of the world, primarily to raise revenue for government expenditures, although they serve other purposes as well' (www.britannica.com). It continues:

$[D]$ uring the 19th century the prevalent idea was that taxes should serve mainly to finance the government. In earlier times, and again today, governments have utilized taxation for other than merely fiscal purposes. One useful way to view the purpose of taxation, attributable to American economist Richard A. Musgrave, is to distinguish between objectives of resource allocation, income redistribution, and economic stability. (Ibid.)

States use taxation to attract business, change consumption patterns, redirect investments, create incentives for sustainable choices and so on'tax legislation for non-fiscal goals is an integral part of government policy' (Gribnau 2015). Already we can see that taxes serve other purposes than merely to provide government, regions, municipalities or other public institutions with income. Increased taxes can redirect consumption by making certain products and services more expensive, thereby counteracting alcohol and tobacco use, for example. They play a role in improving the environment, for example by subsidizing sustainable energy or by diminishing or abolishing taxes altogether on certain products and services in order to make them more attractive. Income redistribution has the 
objective of reducing inequalities of wealth and income among the citizens-or increasing them-or helping certain categories of citizens, for example students, expectant parents or retired people, who are in need during a particular period of their life. Finally, taxes can influence investments in order to provide economic stability or collaborate with other economic policies in order to promote the solid and sound economic development of a given society.

Some nations levy a flat percentage rate of taxation on personal annual income, others on a scale based on annual income amounts; some have marginal taxes where the amount paid increases with income levels; and a few countries impose almost no taxation at all, or a very low tax rate for certain areas of taxation. Some countries levy tax both on corporate income and dividends; this is often referred to as double taxation, as the individual shareholder(s) receiving this payment from a company will also be levied some tax on dividends included in personal income.

A distinction is usually made between direct and indirect taxes. Direct taxes are those whose burden cannot be shifted from one taxpayer to another; one example is an employee's income tax that is directly calculated on and levied from her/his salary. Indirect taxes are levied by an intermediary, who is different from the person who bears the ultimate economic burden of such tax. Although such taxes cannot be directed to specific taxpayers, they are usually seen to have the largest impact on lowincome earners who have, ceteris paribus, less money to spend on consumption than do high-income earners.

The definition of tax is slightly different in the Swedish National Encyclopaedia as it is directly related to the Swedish context: to its historical development, the type of taxes, that it is based in Sweden's democratic institutions, and is clearly connected to the welfare state. The definition says (my translation):

Tax is a statutory payment to the public without direct reciprocity. The constitution stipulates that only the people's representation, the Riksdag, has the right to decide on tax. In the modern welfare state, the need for tax revenue has grown strongly. Important taxes are government and municipal income taxes, VAT, excise taxes on alcohol, tobacco and energy and social security contributions. (www.ne.se, accessed 1.4.2017)

Note that taxation is a payment 'without direct reciprocity'. We will get back to this. Taxes [in Sweden] are levied by the state as well as by county 
councils and municipalities. VAT, excise taxes and social security contributions go to the state while income tax is paid to both state and county councils and municipalities. Regardless of recipient or type of tax, all are collected by one governmental body - the Swedish Tax Agency, Skatteverket.

Researchers suggest a multitude of reasons why taxpayers pay up-or avoid doing so. The usual remedies mostly go hand in hand with researching disciplines: legal scholars want to improve the law (Lodin 2007); economists emphasize economic incitements and punishments (Allingham and Sandmo 1972; Lindbeck et al. 1999; Schneider and Enste 2002; Engström and Holmlund 2006); social interactions theory (Gordon 1989; Fortin et al. 2007) brings in social aspects into economic models explaining tax evasion (Alm 2012: 14); economic psychology tests various social norms in experiments (Kirchler 2007) and political scientists applies for example institutional theory (Steinmo 1996).

Tax compliance research also shows that it is affected by (social and personal) norms such as those regarding procedural justice, trust, belief in the legitimacy of the government, reciprocity, altruism and identification with the group. Studies indicate that certain demographic factors such as age, gender and education correlate with views about tax (Kornhauser 2007; cf. San Juan 2013). To say the least, there are many issues to investigate concerning our willingness to pay.

There are also those who apply a qualitative approach in investigating what people actually do when they collect or pay tax-or avoid doing so. In a social constructivist approach, the description of the practices at the Danish tax authority allows us to understand how tax compliance is effected in a variety of settings. This is always a laborious feat involving the participation of many actors: not only auditors and taxpayers but also the knowledge, technology, rules and regulation that provide active enforcement of these various people (Boll 2011, 2014a, b). These studies show that the state's role in making sure taxpayers comply does not reside (only) inside the state but it is also the effect of a heterogeneous assembly of other actors and practices (Boll 2011: 225). It is a perspective of what tax collectors do when they make taxpayers comply (apparently voluntarily). For other ethnographic studies of tax authorities see Pierluigi De Rosa (2014) on the Italian Tax Authority and Gregory Rawlings and Valerie Braithwaite (2003) on Australians' perspective of their Taxation Office). Similar approaches have been applied by studying tax professionals in US multinational enterprises, showing that these experts have a subtle yet powerful impact on the wider institutional tax environment (Mulligan and Oats 2015); in discussions about taxes on freelancers' 
online forums (Oats and Onu 2016); or in a famous UK case of presumed tax avoidance, where it is shown how the various contenders-tax authority, tax professionals, taxpayers - negotiate both their actions and motives regarding tax regulatory practices (Gracia and Oats 2012). Such qualitative approaches make for 'thick descriptions' of both actors and contexts, with the aim of increasing our understanding of why people behave in certain ways (cf. Geertz 1973). Taxpaying is after all very different in the USA, in Sweden and in Kenya, just to mention a few examples.

What is underscored here is not only how the multitude of disciplines regard tax compliance; the issue is also the methodology used within each discipline (which of course varies). A valid question to keep in mind is how we get to know about how various taxes and taxation methods are understood and accepted by the people paying and collecting them. What can be known and what are the implications of such knowledge? Taking reciprocity seriously also means thinking about how we get to know about reciprocal relations.

\section{RECIPROCITY}

Now we have defined taxation, what about reciprocity-what is it? The word comes from Latin via French, reciprocité. It denotes the status of a relation or an action between people, countries or organizations that is governed by 'a mutual exchange of commercial or other privileges'. There is a mutuality to a reciprocal relationship.

Looking up 'reciprocity' on Wikipedia provides a bewildering number of definitions and usages across many disciplines, which might say more about the contemporary academic tendency to create-borrow-terms across disciplines in order to create 'new' concepts. Compare this with the entry in the Encyclopaedia Britannica from 1988, which only provides a short description referring to the concept's application in international trade agreements. It is defined as 'mutual concessions in tariff rates, quotas, or other commercial restrictions' between countries who sign such agreements. The logical extension is a full customs union, where the encyclopaedia's entry refers to what is now referred to as the European Union (EU). According to an anthropological textbook, reciprocity is '[ $\mathrm{t}] \mathrm{he}$ mutual exchange or obligation. More generally, the relation between people in an economic system, the obligations they have towards each other in such a system, or the practices they engage in in relation to one another' (Barnard and Spencer 1996: 619). In this fiscal anthropological perspective, this is where I put my main emphasis. 
It needs to be underscored that reciprocity is just one of many, many issues that need to be understood if we want to increase tax compliance in society. This book takes reciprocity seriously, yet does not undermine all the other important facets that make taxpayers comply. The multitude of disciplinary research methods and insights does not mean that the research is undertaken in separate silos; despite criticism of particular disciplines by others, there is also much sharing of insights regarding what makes people comply with tax regulations-and avoid them. This book examines all types of research that have addressed the issues of relation building through taxation-reciprocity-and their impact on tax compliance. I want to take account of explanations of what can be said to be reciprocal relations based on ethnographic data and an anthropological approach. This is a book about how the relationships that taxation creates are described from all stakeholders' points of view. Reciprocity is thus not taken as a given phenomenon, but is brought into focus in my interpretation through documents, stories, anecdotes and reflections from Swedes in various capacities.

\section{Why SWEDEN?}

So why Sweden and what can we learn from this relatively small nation? Sweden provides an interesting case when looking at taxation and tax compliance for several reasons.

First, the Swedish welfare state has often been and still is considered a role model (e.g. Svallfors 1995), even if many other countries provide the same level of welfare but perhaps in different configurations. Sweden was a poor and underdeveloped country that grew wealthy during the last century. It escaped both world wars, and industrialization based mainly on rich resources of iron ore and forestry developed without interruption. This growing wealth was the source for simultaneous development of the welfare state as industry and state cooperated and grew for the benefit of each other (e.g. de Swaan 1988; Rothstein 1992; Allvin 2004). The welfare state developed mostly, but not exclusively, under a social democrat government. One political idea during this development was Folkhemmet, literally the People's Home, where all citizens would feel equal (Frykman and Hansen 2009: 80) and where no one would be dependent on or abused by any other (Lewin 2008: 30). The soil for such development was fertile as Sweden was never feudal; the inherent idea of equality might have earlier historical roots than twentieth-century social engineering (Berggren 
and Trägårdh 2006: 52). One of the consequences of Folkhemmet was an evening out of differences in income levels (Bennich-Björkman 2008: 47), and this enhanced equalized standing between citizens, simultaneously provided a foundation for welfare policies through the taxation of personal income from work. However, the Folkhemmet as a place of equality where class adherence would not matter and social mobility might have been the highest in the world is said to be fading away in a global world of increasing income inequalities (Rosenberg 2013: 183).

Second, Swedes pay among the highest income tax rates in the world (Denmark is usually considered to be at the very top). VAT rates are also very high in Sweden by international comparison, although corporate tax rates are more moderate and comparable to those of similar countries. But if we are to take the reciprocal element in tax compliance seriously, Sweden provides a very interesting case because of these high rates. People pay quite a lot and without making too much fuss about it, but they also-as we will see-believe/perceive that they get quite a lot for their taxes. But as in any nation, there are many, many ways to avoid taxation, and citizens also partake quite actively in more or less elaborate tax avoidanceusually on the margins.

The main funding for the Swedish welfare state derives from taxes, of which the largest amount originates from wages or salaries (approximately two-thirds of the total tax collection). ${ }^{5}$ More or less all people that receive income pay taxes, a sum that in total substantiates most of the governments revenue. The reiterative endeavour of building governmental institutions that include most of a population has created a sense of the collective. The contemporary Swedish welfare state can be seen to be the product of collectivization and of corporatist efforts (Rothstein 1992; Rosenberg 2013). This effort has resulted in a modern society that is shaped in its most intimate aspects by this process (Rothstein 1992: 11). Regardless of alternating political regimes in Scandinavia, social expenditure continued to rise during the twentieth century, continuously reinforcing the welfare state and at the same time creating 'a strategic environment in which people operate as calculating entrepreneurs' (de Swaan 1988: 229). This is argued to include both experts who get their income from providing services as well as claimants of these services. Giving and taking is in this view a practice informed by self-interest, although simultaneously contributing to the 'collectivist' construction of the welfare state. 
Corporations also support an important stepping stone in the building of Swedish welfare state. Early on in the social democratic regime, there was a tacit agreement that the state should not interfere in relations between employer organizations on the one hand and labour unions on the other, making for a corporatist agreement between these two parties. This is the very foundation of the Swedish model: peace between opponents on the labour market, economic growth and the encompassing welfare state (Rosenberg 2013: 160). Although these opponents, employers and labour unions, had different views on the level of taxation, there was in essence an agreement about the structure. ${ }^{6}$

Third, the revenue-collecting Agency has a very particular standing, being one of the most revered governmental agencies among the Swedish population today. Much tax research would consider it strange that people pay their taxes without much fuss. In fact, 69 per cent of Swedes think the Agency performs its duties well and only 5 per cent have negative views of this authority (Holmberg and Tryggvason 2014: 11). This has not always been the case (Stridh and Wittberg 2015; cf. Björklund Larsen 2017: 1-3), but the Agency has worked diligently to change its way of working. It mediates the application of law and fulfils the orders of government, but also strives vigorously to be seen as legitimate in its practices by the citizens (e.g. Skatteverket 2008, 2012; Björklund Larsen 2017, Chap. 2). Acquiring legitimacy is achieved by applying strategies such as being serviceable, collecting the 'right'—not the maximum — tax and minimizing taxpayer errors. As the Agency states: 'it should be easy to do it right and difficult to err' (Skatteverket 2014).

Citizens have repeatedly confirmed the Agency's standing in surveys since 2006 (Arkhede and Holmberg 2015: 22, 24). Therefore, the Agency not only enforces laws and regulations but pay attention to the impact they have (e.g. Skatteverket 2007, 2008, 2012). I attended many meetings where this standing was confirmed, following thoughtful and insightful employees who seriously try to engage with how society around them sees taxation (Björklund Larsen 2017). There is a continuous discussion among analysts and managers about the challenges that such an Agency meets in fulfilling its task of collecting the 'right' tax.

Fourth, Sweden is seen as a 'modern society'. According to the World Value Survey's measurements of cultural values, a survey that describes variations in such values among approximately seventy nationalities, Sweden has a very particular position (Ingelhart 2006). ${ }^{7}$ If we are to 
believe such surveys, Swedes are both very rational but also very unlikely to worry about survival issues; they trust both their government and fellow citizens. The World Value Survey argues that there is a continuous inclination towards these values, a fact that makes Sweden appear to be a modern and somewhat trend-setting nation. The question is whether other countries will go in the same direction.

Fifth, it can be argued that Swedes have a direct relation to the state according to both rights and responsibilities, in a type of social contract that is influenced by Rousseau's ideas (Berggren and Trägårdh 2006: 53). Rousseau's contract between citizen and state demands that the individual subject himself to a common will, an idea incorporated in the welfare state (ibid.: 50). Individuals are thus emancipated but also alienated from hierarchical relations, and the welfare state will protect them so that no one has to depend on family or others in order to survive (ibid.: 49), situations in which an individual can easily be taken advantage of. Henrik Berggren and Lars Trägårdh paint a picture of a society of people with equal rights, no one worth more than another. So if one were to attempt to characterize Swedes, they may be described as not wanting to be dependent on each other and thus desiring of symmetrical relations (cf. Daun 2005). They are considered highly individualistic, but at the same time they have a lot of trust in the orderly and rationally organized Swedish state. This seeming paradox is defined as 'statist individualism'. Statist individualism comes out of a deeply rooted and popular democratic view within society, based on the Jante Law rather than originating in people's natural rights of universal equality (Berggren and Trägårdh 2006: 43). This 'law' originates in a book about Danish (and, more broadly, Scandinavian) culture written by Aksel Sandemose in 1933, A Fugitive Crosses his Tracks (English translation 1936). It consists of ten commandments, all determined by jealousy, habits and ways of living in a small town where contacts with the larger world are restricted and social change slow. In common parlance, the Jante Law is unwritten but carries the message that 'thou should not regard thyself as better than any other'. The historical origin of statist individualism is thus argued to go further back than the social engineering of the Social Democratic welfare state during the nineteenth century (ibid.: $49 \mathrm{ff}$ ). It has its background in the history of a nation which was never feudal, where common men have been relatively free in a comparative perspective and where ideas that no one is superior to anyone else are deeply rooted. 


\section{UNDERSTANDING THE RELATIONSHIP BETWEEN SOCIETY AND TAX}

In order to understand any society and its political life, one of the best starting points is taxation (Schumpeter 1954). Schumpeter proposed the view that a nation's fiscal organization and history have an enormous influence on how a nation develops (Musgrave 1992: 90). Taxation is in Schumpeter's view the very foundation of the state; if there is no income the state is unable to act. Unless the state is socialistic, with everything owned by the state and thus no taxation being needed, taxation has to come from citizens and other entities outside the public sector. Taxation both divides the private from the public, but simultaneously connects these spheres.

Although Schumpeter combined a view on taxation from historical, financial and sociological perspectives with his practical experience of having served as a finance minister in the Austrian Republic after the First World War, he took mainly a macro-perspective. Income taxation should be understood as being at the nexus of a nation's economy, the formation of the state governing this nation and the expectations - the values-held by citizens peopling this state (cf. Musgrave 1992: 11). Proceeding to inquire as to why people pay tax to such a state, I turn to the 'new fiscal sociology' as advocated by John Campbell (1993) and especially by Isaac Martin et al. (2009). In their research agenda they move the focus to society's informal institutions such as family, friendships, work and trust, and investigate among other things the determinants of taxpayer consent.

If we take seriously reciprocal relationships as an outcome of taxation, one could argue that reciprocity must be even more pertinent in states with high tax rates - that is, where a large part of the price of a private purchase, as well as net personal income, is tax. There are different explanations for why high tax rates have been accepted: because of war, as some historical research has indicated (e.g. Campbell 1993: 167), but also because of the building of a welfare state. High taxes can be said to originate in the organizational strength of societal groups and of the institutional structure of the state (ibid.: 168). Swedes actually became more content with taxation from 1960 to 1980 despite the almost exponential increase in tax pressure during the period (Hadenius 1985: 362). Research showed that it was not taxation per se that Swedes appreciated, but the benefits provided by it. They got something in return for the taxes paid. 


\section{Fieldwork: Ethnography of Swedes' Views ON TAXATION}

Following Schumpeter, this book takes ethnographic examples from Sweden in order to illuminate how taxation is made possible by highlighting issues and contexts where reciprocity is played out. In what follows you will visit many coffee shops, workplaces and homes to have fika (coffee and cake) with informants, ${ }^{8}$ as well as following me through the corridors of the headquarters of the Agency to attend meetings and interviews. Through these visits, my aim is to illuminate how taxation is made possible in one of the nations with the highest tax 'burden' in the world; albeit one where there does not seem to be so much questioning of taxation.

The data for this book comes from two anthropological studies. In the following I describe the fieldwork but also contextualize the acquired information in time and space.

The first study addressed how informal purchases of work-svart arbete/black work-in Sweden are justified among a group of middle-aged Swedes (Björklund Larsen 2010). These purchases, which look like any other bought work, are said to make up a substantial part of the economy in contemporary society, but are strictly legally speaking tax cheating exchanges. Such exchanges are hidden and subject to ethical, moral, economic and practical considerations, and although politically challenged they seem to exist everywhere.

The societal phenomenon I studied was one that Swedes are constantly exposed to and come into contact with in everyday life-through the media and people's constant engagement with the question. Recurring indignation in headlines caught my attention and a never-ending stream of examples of svart arbete in known and new guises was overheardfragments of conversations at the supermarket, when watching children's soccer games and even when listening to discussions about how to keep within the legal framework at the Scout corps when the youngsters wanted to earn extra income for a trip to a Jamboree in England. There are even humorous advertisements about buying svart in newspapers, relating to stylish leather sofas, or the tip cup at a coffee-shop counter that says svarta pengar.

This study was done in 2003-4 and society around us has changed; the everyday, and justifiable, purchases of svart arbete seem less frequent today. What we hear about now instead are examples of despicable abuses of spart arbete: of immigrants without working permits working for less than 
nothing; of out-sourcing chains of cleaning services where the invoicing provider is completely clean-white-but where subcontractors are hired in an increasingly dirty chain of informal yet organized work and tax swindles; about contractors within the building industry who deliberately dupe the state through avoiding VAT.

Simultaneously, there is also increased awareness among corporations and politicians that everybody should take responsibility for sharing the expenses of the state. The former Social Democratic Party leader Mona Sahlin famously stated: '[I]f you are a Social Democrat, then you think it is cool to pay taxes. Tax is for me the finest notion of what politics is all about.' This is perhaps not surprising; but Per Schlingman, former chief strategist to the Swedish Conservative Party, also agreed with her (although many years later), writing: 'To contribute to the commons is right and responsible and to be unsolidaric is limp.'

Such statements could be written off as political propaganda, yet tax experts within corporations confirm these views. The Chief Financial Officer (CFO) of one of Sweden's largest corporations said in an interview:

There is an increased focus on tax compliance; sometimes the tone in the media - and also coming from certain politicians-is that you should pay more than you ought to (according to his interpretation of the law) - just because we are one of the big, well-known corporations. Then it is difficult to find the right level, both in relation to the public media and in relation to the taxation rules. Yet our decision-making has changed. A decade ago we could consider buying an unprofitable corporation (whose deficits could then be used as a deduction from profits). Such a strategy is unthinkable today; now we only consider the business-related issues in imaginable acquisitions.

The Agency has spearheaded similar thinking. Former Director General Ingemar Hansson argued that tax morals have been changing in Swedish society. In one article he described the resignation by the chairman of one of Sweden's largest pension funds, AMF-a pension fund jointly owned by the Swedish Trade Union Confederation (LO) and employers, via the Confederation of Swedish Enterprises-owing to his tax planning scheme as a change in tax morals. Through his private company the chairman had used a so-called Peru scheme, and the revelation that he had done so made for his resignation from the AMF. The Peru scheme was based on a 
bilateral tax agreement from the 1960s between Peru and Sweden that made it possible to transfer profits from a Swedish company to a Peruvian one, with such profits only being taxed at 4.1 per cent. In a decision by Högsta Förvaltningsdomstolen, the Supreme Administrative Court, in March 2012, such profit transfers were ruled illegal. If the activity generating the profit had taken place in Sweden, taxation on such profits would have been applied there. Hansson argued that this resignation was a sign that taxpayers in general are today less forgiving of tax planning: to pay tax is to show a concern for the society in which the taxpayer works and operates (Hansson 2011; cf. Björklund Larsen 2016).

These small snippets from the public debate illustrate the growing awareness about complying with tax. There are obviously manifold causes and reasons for this change, including the increased automatization and digitalization of taxation issues especially at the level of revenue authorities.

For example, I would suggest that it is more difficult to justify the everyday purchase of svart arbete owing to the introduction of ROT (reparationer, ombyggnad, tillbyggnad-repairs, refurbishing, attachments) and RUT (renhållning, underhåll, tvätt-cleaning, maintenance, laundry) subsidies (in 2007), and the Agency's smart implementation and simplification of using such deductions since then. ROT subsidies have been used now and then to boost the building industry in times of a slack economy. This is an old trick in the finance department's toolkit as the building industry sector is seen as one of the initiators of economic growth in society. ROT subsidies could be used for certain types of reconstruction work in private homes with tax deductions up to a given amount, but also as a way to lessen the propensity for undocumented work. ROT is almost unanimously supported by both politicians and citizens whereas RUT has been subject to an infected political debate addressing issues of gender, inequality and abuse (Gavanas and Calleman 2013). RUT is also a play on words taken from earlier established ROT deductions: Rut is a female name, and women traditionally perform the cleaning in Sweden.

These subsidies make various home services considerably cheaper and the Agency has made it very simple to use them. When ROT and RUT were initially implemented, the reporting and repayment system was cumbersome: one had to pay for the non-deducted services, make sure the provider had registered with the Agency, save all the receipts, add them up, fill in forms at the end of the year with the details of the various providers and finally wait to get a refund several months later-and over a year 
after the first of the purchases was made. Today these subsidized service deductions are already in place on the prepopulated yearly tax return form (for more about the annual tax return, see Chap. 2). Such automatization and simplification of what was once an unwieldy administrative task makes for increased acceptance of such services.

At the time of my fieldwork about how informal purchases of work were made and justified, I had certain concerns (for more detail about this, see Björklund Larsen 2010, Chap. 2). First, it seemed that trust between the informant and me was a necessary ingredient for the interviews to be successful as just posing a question of why and how a person buys services informally could imply accusing this person of illegal actions. This could obviously provide all sorts of replies-anger, contempt, shame but mainly silence. The informant and I have to have some sort of relation in order to address such questions.

Second, more or less every Swede seemed to be involved. Whatever questions you asked regarding informal purchases of work, the answers all seemed to confirm that you could always find what you were looking for (e.g. Portes et al. 1989: 298, Williams and Windebank 1998: 83). Research has also shown that svart arbete is exchanged amongst people of all social categories, ages and political opinions (e.g. Svallfors 1995). Amongst the Limningers, some buy a lot of spart, most take the occasional opportunity to do so and a few refrain from it as much as possible. Thus, looking for an ethnographic field I wanted a group of people who had something in common yet lived and acted in different realms of society. Inspired by Sherry Ortner's fieldwork on class in the USA (cf. Ortner 2003), I contacted the group of people with whom I graduated from school in 1976 in a place I call Limninge. This is a small town in the west of Sweden; hence this group of former classmates is thus collectively referred to as Limningers. As we will see, they provide many different views on what ought to be subject to tax and what should not. They represent diverse social categories and live and work in many different ways in cities, townships, and the countryside throughout the south of Sweden. In the midst of life, they share a long experience of work and life and the memory of our teenage years at the same school I attended. This shared memory provided a platform for trust where illegal yet licit purchases were revealed in ethnographic interviews (Davies 1999: 95-6). Although, these interviews are more than ten years old, I hear the same arguments repeated in contemporary Sweden, although less frequently now.

The second study derives from three years of fieldwork at the Agency where I followed a risk assessment project taking place in its analysis 
department (Björklund Larsen 2013, 2017). This project developed quite naturally from the previous work on svart arbete. In the first study, there was more than one informant who intriguingly posed the question 'what is svart arbete - in reality?' This question was hard to give a direct reply to, as the concept does not legally exist. Recognizing that it was the Agency that has the difficult task of interpreting and implementing the law, I became interested in how they drew the line between what on the one hand could be considered a helping hand and on the other a clearly taxable market trade.

The latest tax reform is from 1991 and made for substantial changes. ${ }^{9}$ Among them, it was stated that all exchanges deemed as having value ought to be subject to tax assessment. This is regardless of whether the recompense consists of money, a service in return or material objects. In theory, the bartering of services compares with exchanges recompensed in cash, and neither the extent of the exchanges nor the relationship between them ought to be considered for tax exemption (Björklund Larsen 2017). This implies that not only is income from (self-)employment taxable, but also that any other exchanges having value that take place between citizens ought to be subject for tax assessment. My interest in how the Agency drew the line here turned into a more specific question about the type of knowledge they apply in interpreting such fickle laws, especially given the Agency's good standing in Swedish society. The analysts thought my questions were interesting, and I was invited to follow this risk assessment project ethnographically.

The project developed into one of the largest risk assessments ever undertaken by the Agency and I was with the project from its initiation, during research meetings, at a random audit control and a research consultancy, and at most meetings when the Agency was informed about its progress. It took three years to finish the report, and interestingly enough the results were deemed too sensitive to be published publicly. Insights from the report were obviously used at the Agency, and new work practices were implemented in the control systems and daily practical audits the following year.

Being with this risk assessment project for three years allows me to bring insights into the broader workings of the Agency and to many aspects of how they interpret the law, how they understand society, how they perform taxation and the relationships they aim to create with taxpayers. Presentations for Agency management about the resulting risk assessment report repeated many previous questions about taxpayers' behaviour. 
Why do taxpayers make errors? Who are these taxpayers? What measures is it possible to reinforce in order to minimize the problems? The discussions that followed were therefore old issues dressed in new clothes. 'It is an interesting subject [why taxpayers make errors] as it pinpoints many issues that are at stake [for the Agency],' said one manager. This fieldwork helps us to understand issues that the Agency considers in its daily work of creating compliance.

Part of the risk assessment project was a random audit control that was of particular interest. A total of 400 entrepreneurs' cost deductions was audited in detail, and the outcome was unexpected. Not only were certain deductions more prevalent than originally thought among a specific category of taxpayers, but questions were also raised about the interpretation of the law in practice. Could such cost deductions even be controlled? Such insights are difficult to communicate, as they contradict not only the message that all taxpayers pay their fair share, but also that the Agency can apply the law equitably and fairly.

Although brief, this book will travel full circle around seemingly opposing actors in the Swedish tax arena. We will get to know why citizens pay taxes from a reciprocal perspective-from people who pay, evade and avoid tax as well as those who collect them.

We know that the behaviour of other taxpayers is important for taxpayers' willingness to comply with tax regulations-or rather the perception that all other taxpayers pay. Many propose reciprocity as one of the explanations. But how is reciprocity explained, invoked, used? When we actually talk about tax compliance in relation to reciprocity, what do we mean?

There are a number of models that apply notions of fairness, altruism, reciprocity, trust, social norms, guilt, shame and morality in various capacities. In this book I will take up the notion of reciprocity, engaging with it from an ethnographic perspective to relay how groups of Swedes discuss such relations. They seldom talk about reciprocity per se, but I am interested in how they articulate the relationship invoked to other taxpayers by the act of having paid, paying and the intention of paying tax-or explicitly avoiding doing so. The ethnographic perspective means taking individuals seriously; both taxpayers and tax professionals (which is a term I will apply to all people working professionally, yet outside academia, with taxation in Sweden). Tax professionals are here mainly employees in various capacities - analysts, managers and so on-at the Agency, but also tax advisors at large auditing firms, CFOs and other employees working with taxation at corporations, and various other experts working with tax issues 
at interest organizations. I therefore use the plural-them-when I write about the Agency. This is acknowledging the employees' voices, opinions and reflections about society and the citizens they are set to tax.

When informants speak about why taxes ought to be paid, or avoided, I do not judge but purely listen in. This especially concerns the Limningers, as their explanations are neither poor excuses nor whitewashes; instead they illustrate how people in their justifications equalize or balance perceived outstanding obligations, both to the state and to other people in society. It is time to take reciprocity seriously. Here I explore it with ethnographic examples from contemporary Sweden in order to add to our understanding of what makes people comply with taxation.

In the following I will go through different strands of research that address reciprocity as an important aspect of what informs our knowledge of tax compliance-not forgetting avoidance strategies. This short recap will also point to the issue of methodology and show that it matters.

\section{Research on Why We Pay Tax}

Research disciplines addressing tax compliance mostly display a benevolent approach and a genuine interest in sharing insights from one discipline and applying them to other methods, analytical approaches and ways of reasoning. For example, economists apply a sense of moral or social obligation to models of economic reasoning (cf. Andreoni et al. 1998: 819). Therefore what follows are excerpts from research in these various disciplines that proposes reciprocity as an explanatory factor.

Reciprocity is said to be one of the explanatory norms in research on tax compliance and evasion (Alm 2012: 12); it is even proposed that the concept will be one of five research directions governing future research on tax evasion (ibid.: 27). James Alm acknowledges the many insights made over the last forty years, yet also articulates many outstanding issues that are yet to be investigated, dug into more deeply or explored; for example, the correlation between issues that are found to explain tax evasion. Thus economics is not the only source of theoretical explanations. I find Alm's proposed five future research strands inspiring. First, he probes for more theories but simultaneously warns us that such theories are contextual; they will probably not 'fit' all individuals and not even the same individual on every occasion. Models are, as always, an attempt to understand and explain reality. In this book (mostly inspired by anthropological 
theory about economic behaviours), I bow to Alm's second proposal that such theories will come mainly from outside mainstream economics. Alm's widely cited article is inspired by the work of George Akerlof and Rachel Kranton (2000) and Akerlof and Robert Shiller (2009), and proposes a view of the economy where 'alternative perspectives' on human behaviour play a role in explaining economic decision-making-tax evasion-in the labour arena. Third, the focus ought to shift from the modelling of individual behaviour to the aggregation of individuals. One implication according to Alm is that we should consider other taxes as well as individual income tax, another is the fact of belonging to groups always has implications on individual behaviour, regardless of whether you call these groups culture, society, organizations or whatever. Alm recognizes that the same individual does not always behave in the same way. Just because I am a woman with an academic degree, who lives in an apartment in a large urban environment and bikes to work does not mean I make the same economic decision every time. I however challenge Alm's fourth proposal, of further laboratory experiments, and his fifth proposal, of controlled field experiments, as ways forward to test proposed theories. Instead I suggest that researchers should direct their gaze to people's lived experiences. There is a world out there, filled with ample examples of people living and acting under a multitude of tax regimes around the globe. In addition to clinical experiments where the modelling of experiments and the posing of questions allows us to construe people's behaviour, we have to ask about and observe what people do and engage with in their everyday life.

The goal for an economist is, of course, to find tools to measure the level of tax compliance or tax evasion and also to identify and explain factors that have an impact. From these, a proposed control of such factors can be suggested. As an anthropologist, it is my modest contribution to present various notions and definitions of reciprocity, beyond the usage of economic and legal literature, in order to contribute to the " full house" of strategies to measure, explain, and control the "full house" of behaviors and motivations' (Alm 2012: 28).

Economists have, for example, tested taxpayers' willingness to comply applying theories of pro-social behaviour, where the argument is that people are more inclined to do what others do. In this vein of tax compliance research, reciprocity means that if other taxpayers pay their due taxes, other citizens would also feel obliged to pay. And the opposite also applies: in a context where many avoid paying tax, the propensity for the individual 
taxpayer to do the same is greater (Rabin 1998; Fehr and Falk 2002). A valid follow-up task would be to make a distinction between copycats and those who comply because there will be more in the treasure chest to share in the society we belong to collectively. Challenging which reciprocity is in play makes for different policies to address non-compliance.

If taxation is considered a social action, the behaviour of individual taxpayers will be strongly influenced by that of others (Frey and Torgler 2007). Frey and Torgler maintain that there is a strong correlation between conditional cooperation of the individual and the extent of tax morale or of tax evasion. It is noteworthy that this research is based on attitudinal data from the European Value Survey: thirty countries were sampled and at least 1000 individuals in each country responded. The following statement, for example, was proposed, offering answers on the scale of 1 (never justified) to 4 (always justified): Cheating on tax payments if you get the chance. The responses were correlated with six variables seen to have an impact on societal tax morale: an individual's voice and accountability, society's political stability and absence of violence, government effectiveness, regulatory quality, rule of law and control of corruption. Frey and Torgler thus stress the importance of political institutions in each of the societies they study, implying that taxpayers' money has been spent on institutions that make for a democratic society and good collective governmental services. The quality of those matters on how citizens interact socially; for example, if others pay taxes so will I. By defining tax morale in this way, Frey and Torgler simultaneously address reciprocity on an institutional level and the perceived expectations of other taxpayers to comply with democratic institutions.

In social behavioural/psychological models reciprocity in relation to tax compliance is dichotomized in various ways; as either strong-weak, negative-positive or horizontal-vertical.

Diving into these dichotomies, we can view reciprocity broadly speaking as people's tendency to respond 'nicely' to actions they are in favour of and 'nastily' to those actions deemed unfavourable for them. If reciprocal feelings are strong, it means that people favour the relationship with others instead of pursuing their own self-interest, whereas if reciprocity is weak the self-interested notions have the upper hand within the proposed exchange (Guala 2012). Negative reciprocity is the result of getting something for nothing, for example stealing (cf. Sahlins 1972), whereas positive reciprocity enforces a common expectation of a positive contribution in return (for something given) regardless if it is in the form of a gift, a 
service, a compliment or a loan. Finally, the vertical variety of reciprocity illustrates the relationship between the public sector and taxpayers (Alm et al. 1993; Frey and Torgler 2007; Bazart and Bonein 2014) and the horizontal variety is the relationship between taxpayers themselves. These relationships have been studied as separate entities in studies of unfairness in taxation, yet as they are both potential sources of unfairness they ought to be studied in tandem (Schnellenbach 2010; Bazart and Bonein 2014).

Reciprocal behaviour is always posed as a response to that of other players-perceived, real, imagined. Reciprocity is a disposition to cooperate with others, but also to punish those who cooperate for reasons of self-interest; it is a norm that makes people comply with tax rules. 'Acting under this norm an individual will respond to another's act in the same way in which that person treated him' (Kornhauser 2007: 9). If a person is treated with generosity and kindness, s/he will respond in kind, whereas if treated badly the response will be in the same fashion. The implication of a strong norm of reciprocity is also said to go for taxes: if others are perceived to pay so will I, whereas if no one else complies why would I (ibid.: 7; Slemrod 1992)? Reciprocity thus needs careful nurturing as its impact on tax compliance can go both ways. As we will later see in the Limningers' justifications, it becomes quite clear that participating in the informal economy, or in the formal for that matter, is taught. We learn to do certain things, among them how to deal with and respond to taxation.

Another distinction is between how taxpayers' money is collected-the fairness of the fiscal system-and how money is spent once collected. Tax evasion can be justified in terms of government expenditure; if I disagree with government policies- how tax money is spent-it is easier for me to avoid paying up (Andreoni et al. 1998). Survey evidence points to similar findings. If government services are not good enough it is easier to evade taxes (Hanousek and Palda 2004), yet we do not know if this is a justified afterthought stated in surveys (Slemrod 2007) or in interviews (Björklund Larsen 2010). Needless to say, such behaviour is influenced by external circumstances; for example, can more taxation be tolerated in times of warfare (Feldman and Slemrod 2009)?

Reciprocal ideas have been subject to the hypothesis that suggests taxpayers 'cheat' if they perceive that their money is not being well spent (Spicer and Lundstedt 1976; Smith 1992). A classic example of such reasoning is Henry David Thoreau's refusal to pay a poll tax, for which he was eventually put in jail. It has been questioned whether his reason was 
that the American federal government did not abolish slavery (cf. Andreoni et al. 1998: 851) or if he was registering a protest against the AmericanMexican war (http://historyofmassachusetts.org/henry-david-thoreauarrested-for-nonpayment-of-poll-tax/); the point is that avoiding payment of tax can be, and has been, used as a protest against what taxpayers' money is spent on.

Suggesting the modelling of such behaviour seems futile, yet attempts are many. For example, a model of a dynamic and retrospective analysis of the relationship between government public good provisions, government waste, considerations about fairness and taxpayer compliance was proposed (Pommerehne et al. 1994). In this experiment taxpayers were repeatedly asked to decide how much to pay reflecting on experiences from the previous period. Individuals were less inclined to comply if waste had been perceived to increase and also if the gap between 'optimal public provision' and actual level widened (cf. Cowell 1990; Bordignon 1993). The challenge is how best to include such effects in theoretical or empirical analysis (Andreoni et al. 1998: 852).

For legal scholars, the notion of reciprocity is approached in terms of relationships between legal subjects, for example the legal (asymmetric) relationship between taxpayer and tax administration (Gribnau 2015), but also between the lawgiver and taxpayers (Gribnau 2013); more specifically in terms of communication. Discussing reciprocity in this way draws on philosophical notions in order to achieve a more equal status in the tax arena where counterparties are by definition unequal.

Such a reciprocal relation between in essence two unequal parties means that a fair exchange has to be carefully maintained (Westerman 2014). Reciprocity cannot be presupposed; it is not given. Instead it is asked if the law itself should be presupposed to facilitate reciprocity as a desirable feat. There is a continuous need for legal and political interventions to secure a fair and equitable relation between citizens (ibid. 184).

And not only between citizens: a tax authority is the right hand of the state and has considerable powers to collect revenue and investigate taxpayers' (economic) lives. It is appropriate to ask, as does Hans Gribnau, what the implications for tax compliance are if the communication of tax law is governed by the principle of reciprocity as opposed to law as topdown command (Gribnau 2015)?

For a tax collecting authority, to enforce compliance through reciprocal norms in this sense means that communication has to be on an equal footing; it also implies that taxpayers at the outset have to respect the intention 
of the law. Leaning on Baruch Spinoza's view of the law means that people by definition obey it and behave according to it; otherwise it cannot be a law. Citizens comply with law even if it conflicts with the moral values they hold; even if the disadvantage of breaking with the moral order is outweighed by the benefits of social order (Gribnau 2015: 196). Taxpayers should not fear the law but respect it for the benefit of societal good. Following this reasoning, it is therefore essential that a tax authority should apply a reciprocal communication when levying taxes. Now, because of the complexity of tax law, there is a lack of legal certainty, and it is up to the tax authority to explain this in a reciprocal, communicative way. This can give rise to unintentional non-compliance-and even overcompliance - resulting in a violation of legal certainty and equality (ibid.: 205-6).

Tax compliance research thus shows a wide range of how reciprocity is applied. Summing up, I see four different ways in which we can speak about reciprocity in tax compliance research.

- The obvious reciprocal relationship is to expect something in return for taxes paid; a tit-for-tat relation. I play on the disambiguity between various definitions of tit-for-tat: of earlier definitions of vengeful and negative reciprocal behaviour and the more recent definitions of getting something back. In experiments based on the 'prisoner dilemma game', tit-for-tat strategies are seen to protect the actor from being abused or to make his intent in exchanging crystal clear. The scrutiny is on receiving something in return for what I have given-for my 'payment' (cf. de Waal 2000). I expect something in return for having given/paid my tribute to the state. There are time lags between giving and receiving something in return, and as Mauss pointed out these time lags have implications for the relation created. To establish good relations, there needs to be an appropriate time lag, otherwise it is just any market exchange.

- Reciprocity implies a relationship with others, so that I as a taxpayer do what other taxpayers do in the sense of wanting to behave in a similar way. This is a copy-cat relation where the reciprocal content is in doing what others, in a similar position to myself, do. Such reciprocity can be invoked for any human behaviour. It is learning by doing what others do. This way of seeing reciprocity is closely related to the notion that we all pay a fair share. 
- Taxpayers comply as they expect others to pay their fair share. If we all put what we owe into the same treasure chest, we have all paid. It is the collectivity of providing means for everybody's benefit. Reciprocity is here articulated as the explicit provision of taxes by all other taxpayers in a given society, and the implicit trust that taxes collected will also be distributed equally and fairly.

- Reciprocity in being treated equally-a question of equality. Here, scrutiny is directed towards the power of the law and interpretation of the same into rules and regulations. There ought to be a reciprocal relationship despite the fact that there is an uneven distribution of power between the collector of taxes and the providers - the taxpayers. This is not only because of enforcement; tax law is by definition complicated, and the tax authority also has immense powers based on its knowledge of tax law that should not be abused.

These four categories of reciprocity obviously overlap. Wanting something for my tax money does not have to be for my individual benefit, but may indicate that I want such money to be spent on societal issues I value and hold dear. A tit-for-tat expectation can go hand in hand with a feeling that other citizens should receive their fair share and be treated equitably.

Leaning on Alm's suggestion of turning to other disciplines when addressing issues that help us to better understand tax compliance, I will use economic anthropology and especially the work done around and following the Gift in order to see what it has to say regarding reciprocal relations. There are a number of insights to be had that draw on descriptions of various types of exchanges and the relations they create. As we will see, there are many types of reciprocal relations invoked when talking about relations created by taxation, at least in the Swedish context. The point is to acknowledge that different types of reciprocity have an impact on tax compliance.

Looking into the many types of exchanges humans engage in and their resulting reciprocal relationships might seem a long walk from the issues of tax compliance, but we will learn something from the relations that exchanges are said to create. After all, recall both the array of explanatory factors proposed by the research on tax compliance above as well as Swedish tax law. To repeat: the latter states that anything with value that is exchanged, regardless of how it is remunerated, ought to be subject to tax. 
Choosing which exchanges to tax ought to be subject to careful consideration in order to create voluntary compliance, but also to steer attention towards what citizens ought to get in return for their contributions. Although Sweden is a small and 'exotic' nation in the values its citizens hold, understanding the relations that taxation create in that country ought to be of interest to other nation states-for other tax law legislations.

\section{Anthropology of Economic Exchanges AND RECIPROCITY}

Marcel Mauss regarded gifts as 'total social phenomena' (Mauss 2016: 58), meaning that a gift draws on an immense number of societal aspects and institutions. This one-way transfer of a good creates relations and is thus a way in which social relations within society can be defined. According to Mauss's study, the obligations of the gift are three in number; to give, to receive and to reciprocate - that is, to give again (Mauss 2002 [1990]: 9).

Something given provokes reciprocity in human relationships, thereby complicating them. The recipient feels forced to respond, starting a chain of other exchanges, dispersed with different time intervals that will govern future relations. It is important to underline that the gift does not necessarily start a good relationship; having received something, the recipient can also choose not to respond (Davis 1992: 24, Mauss 2002 [1990]: 17), whereby the relationship will deteriorate or end. Those who give and those who receive might have very different capabilities for reciprocating in terms of an equal relationship. In this way reciprocity can also be exclusive, as those who give much also receive much. 'Apparently, reciprocity is not morally good in and of itself: reciprocal acts do not necessarily lead to a more just or fair society' (Komter 2014: 161). The gift, either altruistically given (Gudeman 2001: 80) if there ever was one (cf. Derrida 1995), or the one meant to create reciprocity, is identified with the contributor, and the gift's intention is thereby real, changing and ambiguous (Davis 1992: 79). A gift offered might at first sight be provided out of sympathy with the recipient, but less noble intentions might be hidden-a quest for attention, blandishment, manipulation or even bribe (Komter 1996: 3).

Reciprocity is a relationship constructed out of exchanging something for something else; it is a mutual obligation people have towards each other following an exchange. Reciprocity has been part of anthropology 
since anthropologists started to cast their gaze towards how people lived and exchanged; investigating the economy if we can set householding, survival and other means of existence apart from people's everyday life. The concept has therefore often been used to address relationships in primitive but also informal and non-market economies.

Reciprocity is the outcome of an array of human exchanges; from altruistic gifts, via market transactions to pure theft, where the exchanged items have been food, services, commodities, land, sacred items and the ultimate gift-the woman (Levi-Strauss 1966: 204). Reciprocity as an explanatory factor has in anthropological literature been applied to many a context: emotions among Swedish civil servants (Graham 2002); everyday sustainability among sugarcane workers in Brazil (L'Estoile 2014); beggars in Rome (Thomassen 2015); US garage sales (Herrmann 1997); and even in the concentration camp of Auschwitz (Narotzky and Moreno 2002), just to mention a very few examples.

One of the examples that Mauss drew on in his book was the kula trading system in the Trobriand Islands. Bronislaw Malinowski, a Polish anthropologist educated in England, was stranded there during part of the First World War and had ample time to investigate the economy, the householding and the intricacies of exchange among the Trobrianders. He described the kula exchange that took place between islanders when visiting each other. This was a ceremonial exchange, used to create relationships and obligations (Malinowski 1966 [1922]). A giver presented a valuable armband or necklace to his host with much ceremonial brouhaha, showing the more or less discreet pleasure of drawing the recipient into a relationship where the latter needed to provide a countergift. This countergift could not of course be reciprocated directly, but had to be given on a suitable future occasion. Noteworthy is that not all exchanges were considered kula - on the contrary, among the Trobrianders it was important to distinguish them from the barters and purchases of everyday necessities.

The quality of things exchanged matters and so does the quantity. The person in society who receives the largest gifts has most status. As s/he must reciprocate, one assumes that $\mathrm{s} /$ he has more than what $\mathrm{s} /$ he receives, making her/him able to reciprocate with an even bigger gift. If unable to do so, her/his status dwindles. A too large gift, such as almsgiving, degrades the recipient, especially if it is given without expecting a gift back (Mauss 2002 [1990]: 95). 
Moving our scrutiny to contemporary Italy, more specifically amongst the popolino in Naples, ${ }^{10}$ the recipient of many gifts is considered privileged because status in society increases with gifts (Pardo 1996: 154). Many gifts imply that the donor has resources that has been or will be used. There is a fine line between this position and receiving too much without reciprocating: if society considers the reciprocal action to be too slow or not reaching expected levels, esteem will turn into contempt. The recipient's superiority as net provider is no more; instead the reputation of a net receiver is acquired and a status of dependence manifests itself (Cuco i Giner 2000: 315). Pure charity hurts a recipient's pride and his/her status in society diminishes if there is no possibility of reciprocating the gift (Mauss 2002 [1990]: 83). Politics of welfare can simultaneously foster solidarity between society's members but also exclude net receivers, in their own and other's view, as they have no means of reciprocating (Komter 1996: 7).

But what is it that creates the relationship? Is it what is given or who the giver is? Mauss described the reciprocal relation created by the gift as a spirit, the hau, which he borrows from the Maori in New Zealand. This spirit of the gift-giver resides within the thing given and stays with it until reciprocated; 'to accept something from someone is to accept something of his spiritual essence, of his soul' (Mauss 2016: 73). This was criticized by Raymond Firth, who instead showed that this spirit was within the gift given, not with the person who gave it (Firth 1959). There are thus various views of who carries the spirit; whether it is the something that is given which is of importance, or the person who gives it.

The most common exchange in modern society is the market exchange. ${ }^{11}$ Both Mauss and Marshall Sahlins in his study of stone-age economics (see below) left this out of their analysis, and the existence of a market transaction in primitive societies is contested. A market transaction was originally defined as being exempt from creating reciprocal relations; it was supposed to be a spot exchange performed through profit maximizing and by unsocial actors (Swedberg 2003), but has in later studies been shown to result in different types of reciprocal relations as well (e.g. Befu 1977; Davis 1992; Offer 1997). I will delve into the market transaction in what follows as it plays a fundamental role in taxation. It is market exchanges that first comes to mind when we think about exchanges subject to tax.

The modern market trade has money as a means of settlement in return for a product. The exchange is usually based on a predefined price. The 
producer does not have any contact with the consumer, who instead buys from an intermediary via an institutionalized shop. Buying a litre of milk in contemporary Sweden is done from any kiosk, service station, grocery or supermarket and is hardly ever bartered from a person owning a cow. A sweater is purchased on appearance and a book on content, but the consumer identifies the product with the store or the brand and not with the salesperson. If the product is faulty and the consumer complains, the response to the complaint most likely influences the next purchase. If the milk is sour it's poured away, and it's no big deal unless it happens again. If the sweater shrinks or the book has pages missing, it does not live up to expectations. The salesperson is an intermediary with whom to negotiate, but is seldom the direct target of blame. When buying a commodity for money, the spirit of the provider of the gift is gone.

The spirit of the transaction can help explain the quality of the relationship between the counterparts in the exchange, regardless of whether the transaction is a pure gift or a market deal. Talking about spirits within a modern market transaction can sound strange, but there is something beyond the simple exchange of money for a product/commodity. There is a lingering feeling of getting good value for money spent, some sort of spirit residing with the object bought. If what is bought doesn't live up to expectations, doesn't work or fails for some reason, we blame the providerproducer. The thing acquired can be exchanged for a new object, backed up by receipts and warranties and the entire legal structure behind these simple pieces of paper. When exchanging services, there is no object exchanging hands. Thus, the spirit, if we continue to call it thus, of the transaction dwells within the resulting work, even more explicitly with the provider if the work done exceeds our expectations. And the opposite is equally important: poorly done work irritates us. This feeling remains with the work done even after the service has been rectified and the provider and customer ought to be quits.

Even the latter examples demand varying amounts of reciprocity-food is bought at the local grocery to support local industry, a friend's garage is used for car repairs in order to sustain the friendship: it is the repetition of market exchanges that creates relations. Reciprocity can be discussed and defined theoretically, but reality depends on the context (Gregory 1994: 936). Although the self-interest increases with the distance in the relation (Komter 2014: 161), we can see that the accumulation of exchanges creates reciprocal relationships regardless of where the exchange takes place. 
Existing social relationships thus create different motivations to reciprocate even in the market. There is therefore a continuum of reciprocal types depending on the intent behind the exchange.

\section{Reciprocity Proliferating}

Regardless of whether a transaction is an altruistic gift or a market transaction, the resulting reciprocity describes the quality of the relationship between the counterparts involved in the exchange. A reciprocal relationship does not imply an immediate repayment. The time between what is given and what is reciprocated is of vital importance. A direct reciprocating return can be experienced as an offence to the existing relationship; in the worst case the relationship will be terminated (Davis 1992: 85; Ledeneva 1998: 167). An immediate return makes the gift into a market transaction, whereas delayed reciprocity makes us hope for a future possibility of receiving something if we need it ourselves. One example given is donating blood (Komter 2014). This is a type of indirect reciprocity, where 'I scratch your back, you scratch another person's back and that person scratches mine' (ibid.: 162).

Reciprocity can also be described in terms of debt or obligations. When we receive something, we have to reciprocate in some way; it is how we do this that defines our standing in society. The distinction between different types of moral reasonings when you are in debt, in debt economies (High and Hall 2012), matters to many people. Being in debt makes us focus on the time aspect between what is given and received, although in Holly High's argument it becomes more: debt becomes another type of a total social phenomenon about which we can have diverse moral reasoning.

A seminal way of thinking about reciprocity was proposed in a study of stone-age economies (Sahlins 1972). There were three defined types'negative', 'balanced', and 'generalized' reciprocity. First, generalized reciprocity is described as mainly taking place within the family. Generalized reciprocity is giving without expecting something in return. These give and take relationships occur between kin or close subjects who have many other social relations than those based on exchanges. Outside the family there is balanced reciprocity, which is the result of exchanges within a community. Also called symmetrical reciprocity, it is more like a transaction between neighbours where both parties are believed to benefit in the long run. The return of the given goods or service supposedly takes place 
at some future date, so the exchange is based on a fair amount of trust and social connectedness. The third and final type of reciprocity is negative, with examples such as theft and barter, where one of the subjects involved in the exchange earns at the expense of the counterpart. This relationship is one of enemies or between strangers. The reciprocal categories are thus related to modes of social organization (house, lineage, village, tribal, intertribal).

Sahlins's work has been criticized. Perhaps it is an 'overstretching of the notion of reciprocity to cover transactions that are clearly not reciprocal at all such as "generalized reciprocity" for sharing and "negative reciprocity" for stealing' (Widlok 2013: 15). Second, the claim that generalized reciprocity always implies close kinship relations does not empirically stand up to the fact that sharing has been observed at times to be indiscriminate in regard to specific kin relations. Sharing may in certain context include everyone present, even 'distant' visitors or anthropologists who are not treated as close kin in other contexts (ibid.: 15-16).

This is an important point, yet almost tautological. In Sahlins's structural analysis, there are set rules for exchanging that depend on existing relations, yet as Thomas Widlok shows such rules are manners or traditions that make for developing relations between people. It is the very notion of sharing with strangers that creates reciprocity. In many societies, it is good manners to behave this way and to be generous, as the generosity will eventually get back to us when we are visiting someone else. It is reciprocal.

So back to the source. Even if Marcel Mauss wrote about the Gift, he rarely applied reciprocity as a term and perhaps did not even give it much thought, but rather only applied it to the habit of giving something back for what has been received. However, the discussion in Mauss's book about the gift suggests that 'reciprocal' is more than a practice; it is an obligation, a feeling (MacCormack 1976: 97)—regardless of whether or not we denote it as a spirit. Reciprocity as a concept should therefore be used with greatest caution. MacCormack's critique was aimed at researchers' sloppy distinction between the social phenomenon itself and the usage of the term as a 'tool of analysis' (1976). ${ }^{12}$ On the one hand he observed that it is difficult to denote what exactly is happening in an exchange when applying reciprocity as an explanatory concept; if it is used emically describing a custom or if it is a necessity for survival. On the other hand, reciprocity is also used etically to analyse exchanges in certain societies (ibid.: 101). 
My critique of tax compliance research as inadequately explaining the type of reciprocity as an explanatory factor could be said to follow Geoffrey MacCormack's path. The point of this book is to show the manifold guises that reciprocity takes in taxation. Reciprocity needs to be recognized in all its different aspects when we think about why people pay tax.

I thus see versions of reciprocity to be the result of most exchanges, regardless of the context in which they take place. Exchanges within the family, with kin, friends and acquaintances, on the so-called market and in politics all create diverse types of reciprocal relations (Graeber 2001; Hart 2007). This view also means that diverse types of exchange are possible with the same counterpart (cf. Callon and Latour 1997), and that the outcome of an exchange does not need to be material or monetary but can also be entirely social (cf. Befu 1977).

Critiques have emphasized that the concept of reciprocity is too diffuse and devoid of the power dimension, and is thus meaningless as a comparative explanatory factor (Graeber 2001: 217). Yet the beauty of Mauss's argument is that it is not definite (cf. Maurer 2016: $\mathrm{x}$ ). The argument in The Gift allows us to think about what the reciprocity existing in the world can entail and to consider that relations matter. Bill Maurer points out in his foreword to the most recent translation of The Gift (2016) that Mauss does not provide us with a final argument about the causality of reciprocal relations, but rather sketches what societal possibilities such relations carry with them-and also the implications if we do not make room for reciprocity in society. ${ }^{13}$

This is also the role of The Gift in this book. I follow a long tradition of thinking with reciprocity, and have outlined above a few of the many thoughts about how we can understand exchanges in terms of reciprocity and especially the type of (reciprocal) relations that taxation create. In the following I want, instead of trying to define what reciprocity is and is not, to think about contemporary Swedish varieties of tax compliance, invoking instances where reciprocity can be said to be at play.

The point is that many different types of exchange and the resulting more or less reciprocal feelings exist side by side in any society. Reciprocity is thus used as the concept describing these relations, not only as the practice of exchanging things for mutual benefit. The act of giving and receiving - exchanging - is not only a 'total social phenomenon' but also a universal human trait. Exchanges might not be the origin of society, but 
can be argued to hold society together (Befu 1977: 255) as they create personal relationships between actors. By exchanging, people create, nurture and maintain relations between each other.

\section{To See Tax as a GifT-Or?}

So more specifically, what is its role in taxation? Returning to Mauss, at the end of The Gift he moved the analysis from historical accounts and 'archaic' societies and indicated implications about what the gift would mean for the then contemporary society (about 100 years ago), when discussions and political initiatives had started to shape at least the contours of a welfare state. His concerns were about what (economic) exchanges do to men's morale, and maybe shared morals (Hart 2007: 481), and thus ultimately how society is politically shaped. ${ }^{14}$ Reciprocal exchanges provide the normative foundation on which the welfare state is based as it implies a moral regulation of dependencies in a system of rights and responsibilities' (Jacobsson 2006: 21, my translation).

But ' $[t]$ axes are not a gift', states Jacques Godbout. He disagrees with Mauss in that a state and the gift 'system' are complementary. The state fulfils its distributive role in two very different ways: first, through complete anonymous indirect or direct monetary transfers; second, as a dispenser of various services: for example, social, health, support, schools. 'The state system tends to make decisions independent of personal relations and characteristics, on the basis of abstract criteria derived from rights' (Godbout and Caille 1998: 61). It is the democratic law that decides who should receive 'gifts' from the state, not by market selection but by a political decision about what the collectivity of citizens should acquire. As we know, this varies greatly between nation-states. From the state's perspective, citizens are both 'taxpayers', providers of revenue, and 'clients', recipients of governmental services. Godbout argues that the phenomenon of the gift is subjective and a potential source of [great] inequality, which is something a state should deter.

I partly agree with Godbout if we take the state's perspective. However, turning to the perspective of the taxpayers - the citizens-and looking at the entire system of taxes and what they provide, taxes can certainly be seen as at least containing reciprocal relations. Taxes have been giventaken is perhaps more appropriate as most taxpayers do not have a choicebut there is clearly an expectation of receiving something in return, of 
relating to others receiving similar things and also making sure that we all contribute in some way. It is the state in its capacity of democratic institution that decides what will be returned, not as a personal gift but rather to selected categories of citizens.

Therefore, we are interested in the views that citizens - taxpayers-have of the authorities, and the views that authorities have of taxpayers. Ultimately, the latter has to be persuaded to comply with taxation; thus they make the state possible (if the state does not have other income).

'A strong inner feeling of being morally obliged to return the gift is the quintessence of real-life reciprocity' (Komter 2014: 162). So when we as citizens who belong to a certain society pay into a common coffer for financing things that we all ought to benefit from, we simultaneously create expectations of getting something in return while also creating expectations that all other citizens will provide their fair share at some point.

\section{CONCLUSION}

The gift carries with it three obligations: to give, to receive and to give again. And this is also what taxes make us do if they should sustain. In our contemporary societies, there is an endless giving and receiving going on with state and with society - every day and in manifold different ways. Against this background it is interesting to explore taxation in terms of reciprocity.

We saw in research about taxation that four different types of reciprocal relation could be identified. First, reciprocity that expects something very explicit in return for taxes paid; a tit-for-tat relation. I expect something in return for having given/paid my tribute to the state although, as Mauss stated, obviously time lags between giving and receiving something in return. Second, it implies a relationship with others in the sense of wanting to behave in a similar way. Reciprocity here is a copy-cat relationship. Such a reciprocity can be invoked by any human behaviour: it is learning by doing what others do and making sure we do the same thing. This way of seeing reciprocity is closely related to situations where we all pay a fair share - the third type-when taxpayers comply because they expect that others will pay their fair share. If we all put what we owe into the same treasure chest, we have all paid. Implicit here is our trust that taxes collected will be distributed evenly. Finally, reciprocity also regards being treated uniformly-it is a question of equality. Here scrutiny is directed towards the power of the law and the interpretation of the law through 
rules and regulations. There ought to be a reciprocal relationship, despite the fact that there is an uneven distribution of power between the collector of taxes and the providers - the taxpayers. This is not only because of enforcement; tax law is by definition complex, and the tax authority has immense powers through its knowledge of tax law, which should not be abused.

What follows is an exploration of the concept of reciprocity played out in different ways in the Swedish tax arena. Reciprocal relations are taken seriously, yet they are perceived and imagined relations pronounced by the very actors that deal with taxes in practice-taxpayers and tax collectors. You will meet some of the Limningers, a group of middle-aged Swedes, and hear their reasoning about taxes in terms of reciprocity. You will also become acquainted with employees at the Agency in order to hear their views of reciprocity as played out in taxation and how they see the challenges facing Swedish taxpayers in contributing their fair share. The book ends with the proposal of a fifth type of reciprocity that has to be considered when understanding tax compliance, taking account of people's propensity to exchange. It is the quid pro quo exchange, the common, everyday transaction between people where the state is left out of the deal.

In Chap. 2, Taxpayers' Relation to their State, we will deal with taxation as a reciprocal relationship between taxpayers and the state they live in. We will explore taxpayers' perceptions of contributing with taxes, or receiving from the common treasure chest, and what this has do to seeing taxation as part of a reciprocal relation. Chapter 3, Taxpayer to Taxpayer Relation, moves the focus to explore the reciprocal relation that taxpayers create among themselves as an implicit result of taxation. As Sweden has a law that says all exchanges have value, regardless of how they are compensated, they ought to be subject to tax assessment. We will see how Swedes exchange in private and how reciprocity is invoked to keep out the state. Chapter 4 highlights the tensions that are created between perceptions of who pays and who receives in society. The focus is on balancing a reciprocal equilibrium. Swedes assess the taxes they pay not only in relation to what they receive, but also in relation to other residents-they compare their contribution with perceptions about what fellow citizens pay and receive. In Chap. 5, I conclude by proposing that the quid pro quo exchange should be included in the array of reciprocal relationships that impact tax compliance. The final take home from all the expectations is that if we are to actively create a legitimate taxation regime, all taxpayers need to contribute. 


\section{Notes}

1. I am grateful to Hans Gribnau who directed my attention to this.

2. It could be more. Animals also are known to exchange things, for example chimpanzees (e.g. de Waal 2000) but as monkeys do not pay tax-yetthat is outside the scope of this book.

3. There are many other taxpayers - but the focus in this book is on human individuals and their relation to taxes and taxation.

4. Taxes are, as we saw in the introduction, used for many purposes, and one of these is wealth redistribution. In Karl Polanyi's seminal analysis of the economy, reciprocity was one of three behavioural principles governing primitive economies, drawing on Malinowski's account of exchanges in the Trobriand isles (1966 [1922]: 59). Reciprocity was described as a symmetrical relationship not only between kin, where obligations and help were given and received, but also as the principle governing the exchanges of bracelets and necklaces within the kula-ring that he borrowed from Malinowski's research. A second principle was the autarkic production and consumption within an economic unit described as householding. On a community level, there was a third type of economic behaviour, described as redistribution. These are contributions given to the chief for storage and future use in community activities such as feasts, trade with other islanders and ceremonial gifts. Reciprocity is an all-encompassing phenomenon but exclusive to tribal societies. Polanyi notes that all social obligations in tribal societies are reciprocal, and fulfilling them serves the individuals give-andtake interest best (Polanyi 2001 [1994]: 48).

Polanyi's three concepts are both descriptive and evaluative, having a moral content. In today's modern society we can associate many exchanges with the three exchange principles, although they appear more blurred, as hazy contours in exchanges mostly governed by monetary market principles but where the state also takes its share. Hardly any transaction within a modern welfare state takes place without the state getting a share of it. From citizens to state, redistribution takes place in the forms of income tax, VAT, pensions, employers' social fees and taxes on gains from capital, inheritance, house sales and so on. The state redistributes these earnings mainly as infrastructure and discounted services, but also directly to households through child allowances, pensions, education benefits, housing subsidies and so on. Redistribution in a modern welfare state such as Sweden is an undisputed fact, not contested and taken for granted by most citizens. It is the amount and encompassment of the redistribution which is contested, expressed in contemporary political ideologies.

Taxation was briefly mentioned in The Great Transformation in a very few places. Polanyi saw it as a kind of redistribution because taxation always 
takes place via the ruler; taxes are paid to the ruler, and the way s/he spends it and redistributes taxes is a political act. Reciprocity thus did not govern taxation. Although Polanyi firmly places taxation under the umbrella of redistribution, we are interested in taxpayers' views on their own contribution vis-à-vis other taxpayers as well as what they receive in return-reciprocity. It is not redistribution that is in focus here; it is the relations created by the very fact of paying taxes.

5. There are currently four main types of Swedish taxes and the Agency is responsible for administrating and collecting all of them. Income tax provides the main funding for municipalities and provinces and makes up about two-thirds of the total tax collected. Income tax is basically applied to all types of personal income including work, pensions and sickness benefits and includes indirect tax on work in the form of social fees. This latter tax is typically paid by the employer on behalf of the employee and does not show in tax returns. The actual tax percentage on income is thus far larger than what is shown on individual tax statements. Second, there is VAT (value added tax-moms), which is included in all consumption prices for private individuals. It is a governmental tax and amounts to almost 20 per cent of total tax collected. The third largest tax comes from capital, mostly on surplus from corporate activity, and amounts to close to 10 per cent. Excise, import and some other small varieties make up the remaining 10 per cent.

6. Quote from Professor Emeritus Sven-Olof Lodin at Skatteakademin, 2015.

7. The result is visualized on the Inglehart-Welzel Cultural Map of the World, showing the vertical axis with 'traditional values' at the lower end escalating towards 'secular-rational values'. On the horizontal axis, 'survival values' are set against 'self-expressional values'. Sweden displays an extreme result on the graph compared with other countries, being situated in the extreme upper right-hand corner.

8. Fika, a coffee break, is a common occasion for socializing in Swedish society, at home or in the workplace when taking regular breaks over a cup of coffee or tea, sometimes accompanied by sweet breads or cakes. As a verb you can also $f i k a$, have a coffee break, with friends. At almost all interviews, I had fika with the informants.

9. The tax reform was seen as one of the most radical reforms in any industrialized country in the postwar period (Agell et al. 1996; Steinmo 2002: 840).

10. So-called ordinary people without secondary education in Naples.

11. This of course depends on how you define an exchange. Thinking with Harumi Befu that exchanges can include social ones-agreements, communications, services or other movements between separate units or beings (Befu 1977)—the market appears less dominant. 
12. This is perhaps why The Handbook of Economic Sociology omits the term, but referring to the work of Max Weber rather speaks about what constitutes an economic relationship.

13. For Bill Maurer, the issue is more methodological. For him, 'the Gift is illuminating a particular notion of the alternative' (2016: xiv). It makes us think that there can be other ways of exchanging, other ways of organizing society. What would '[a]nother law, another economy and another mentality' (ibid.: xiv) make of society?

14. This does not exclude money as a means of exchange. Although Mauss has been interpreted as excluding money from reciprocal relations, for example writing 'that our morality is not solely commercial' (Mauss 2002 [1990]: 63), he also alluded to citizens' relationship with the state and to employers, as he does at the end of The Gift; there is necessarily also a concern about money in relation to talking about the state providing social insurance.

\section{LiTERATURE}

Agell, Jonas, Peter Englund, and Jan Södersten. 1996. Tax Reform of The Century-The Swedish Experiment. National Tax Journal 49 (4): 643-664.

Akerlof, George A., and Rachel E. Kranton. 2000. Economics and Identity. Quarterly Journal of Economics 115 (3): 715-753. https://doi.org/10.1162/ 003355300554881

Akerlof, George A., and Robert J. Shiller. 2009. Animal Spirits: How Human Psychology Drives the Economy, and Why It Matters for Global Capitalism. Princeton, NJ: Princeton University Press. https://www.google.com/ books?hl=sv\&lr=\&id=2Rz_cuu $88 \mathrm{DwC} \& o \mathrm{i}=$ fnd $\& p g=P R 7 \& d q=$ animal + spirits +akerlof+shiller+2009\&ots=HvzT_P98wA\&sig=YJpa64_nQU1RtpoN2fdCxYNBfQs

Allingham, Michael G., and Agnar Sandmo. 1972. Income Tax Evasion: A Theoretical Analysis. Journal of Public Economics 1: 323-338. http://scholar. google.se /scholar?hl=sv\&q=sandmo\%2C+agnar\&btnG=\#0

Allvin, Michael. 2004. The Individualization of Labour. In Learning to Be Employable. New Agendas on Work, Responsibility and Learning in a Globalizing World, ed. Christina Garsten and Kerstin Jacobsson, 23-41. Basingstoke: Palgrave Macmillan.

Alm, James. 2012. Measuring, Explaining, and Controlling Tax Evasion: Lessons from Theory, Experiments, and Field Studies. International Tax and Public Finance 19 (1): 54-77. http://link.springer.com/article/10.1007/s10797011-9171-2

Alm, James, Roy Bahl, and Matthew N. Murray. 1993. Audit Selection and Income Tax Underreporting in the Tax Compliance Game. Journal of Development 
Economics 42 (1): 1-33. http://www.sciencedirect.com/science/article/ pii/0304387893900704

Andreoni, James, Brian Erard, and Jonathan Feinstein. 1998. Tax Compliance. Journal of Economic Literature 36 (2): 818-860. http://www.jstor.org/ stable $/ 2565123$

Arkhede, Sofia, and Sören Holmberg. 2015. Svenska folkets bedömning av offentliga myndigheters verksambet (Report 19). Göteborg: SOM institutet.

Barnard, A., and J. Spencer. 1996. Encyclopedia of Social and Cultural Anthropology. London and New York: Routledge. https://www.google.com/books?hl=sv\&lr= \&id $=$ ReZAlcV7TckC\&oi=fnd\&pg $=$ PR9\&dq=Encyclopedia + of + Social + and $+C u l$ tural+Anthropology\&ots=hZZz7gkBIK\&sig=j_fJenBlaItFxPo4TyUY2G-0Yz8

Bazart, C., and A. Bonein. 2014. Reciprocal Relationships in Tax Compliance Decisions. Journal of Economic Psychology 40: 83-102. https://doi.org/10.1016/j. joep.2012.10.002

Befu, Harumi. 1977. Social Exchange. Annual Reviews in Anthropology 6 (1): 255-281.

Bennich-Björkman, Li. 2008. Medborgarsamhället. politisk kultur och politiskt beteende i Sverige. In Mellan folkhem och Europa, ed. Li Bennich-Björkman and Paula Blomqvist, 40-62. Liber.

Berggren, Henrik, and Lars Trägårdh. 2006. Är svensken människa? Gemenskap och oberoende $i$ det moderna Sverige. Stockholm: Nordstedt.

Björklund Larsen, Lotta. 2010. Illegal yet Licit: Justifying Informal Purchases of Work in Contemporary Sweden. ACTA UNIVE. Stockholm: Stockholm Studies in Social Anthropology N.S. 2. http://su.diva-portal.org/smash/record. jsf?pid=diva2:287414

_ 2013. The Making of a 'Good Deal' Dealing with Conflicting and Complementary Values When Getting the Car Repaired Informally in Sweden. Journal of Cultural Economy 6: 419-433. http://www.tandfonline.com/doi/ abs/10.1080/17530350.2013.827989

- 2016. SWEDEN: Failure of a Cooperative Compliance Project? FairTax Working Paper No 7. Umeå.

- 2017. Shaping Taxpayers. Values in Action at the Swedish Tax Agency. Oxford: Berghahn Books.

Boll, Karen. 2011. Taxing Assemblages. Laborious and Meticulous Achievements of Tax Compliance. Copenhagen: IT University of Copenhagen.

- 2014a. Mapping Tax Compliance. Critical Perspectives on Accounting 25 (4-5): 293-303. http://www.sciencedirect.com/science/article/pii/ S1045235413000270

. 2014b. Shady Car Dealings and Taxing Work Practices: An Ethnography of a Tax Audit Process. Accounting, Organizations and Society 39 (1): 1-19. http://www.sciencedirect.com/science/article/pii/S0361368213001001 
Bordignon, Massimo. 1993. A Fairness Approach to Income Tax Evasion. Journal of Public Economics 52 (3): 345-362. http://www.sciencedirect.com/science/ article/pii/004727279390039V

Callon, Michel, and Bruno Latour. 1997. 'Tu Ne Calculeras Pas!' Ou Comment Symétriser Le. In Le Capitalisme Aujourd'hui, ed. Alain Caillé, 45-70. Decouverte. http://www.bruno-latour.fr/sites/default/files/P-71-CAPITALISMEMAUSS-FR.pdf

Campbell, John L. 1993. The State and Fiscal Sociology. Annual Review of Sociology 19: 163-185. http://www.jstor.org/stable/10.2307/2083385

Cowell, Frank. 1990. Cheating the Government: The Economics of Evasion. Cambridge, MA: MIT Press.

Cuco, I., and J. Giner. 2000. Proximal Paradox: Friends and Relatives in the Era of Globalization. European Journal of Social Theory 3 (3): 313-324.

Daun, Åke. 2005. En stuga på sjätte våningen: svensk mentalitet i en mångkulturell värld. Eslöv: Brutus Östlings Bokförlag. https://scholar.google.se/scholar?hl =sv\&q=En+stuga+på+sjätte+våningen $\% 3 \mathrm{~A}+$ Svensk+mentalitet+i+en+mångkult urell+värld\&btnG=

Davies, Charlotte Aull. 1999. Reflexive Ethnography. A Guide to Researching Selves and Others. London: Routledge.

Davis, John. 1992. Exchange. Minneapolis: University of Minnesota Press.

De Rosa, Pierluigi. 2014. Building Trust in Italian Tax Authority. An Ethnographic Approach. Rivista Internazionale di Scienze Sociali 124 (1): 103-130.

de Swaan, Abram. 1988. In Care of the State: Health Care, Education and Welfare in Europe and the USA in the Modern Era. Cambridge: Polity Press.

de Waal, F.B.M. 2000. Attitudinal Reciprocity in Food Sharing among Brown Capuchin Monkeys. Animal Behaviour 60: 253-261. http://www.sciencedirect.com/science/article/pii/S0003347200914714

Derrida, Jacques. 1995. The Gift of Death. Vol. 25. Chicago: University of Chicago Press.

Engström, Per, and Bertil Holmlund. 2006. Tax Evasion and Self-Employment in a High-Tax Country: Evidence from Sweden. CESIFO Working Paper No. 1736.

Fehr, Ernst, and Armin Falk. 2002. Psychological Foundations of Incentives. European Economic Review 46 (4-5): 687-724. http://www.sciencedirect. com/science/article/pii/S0014292101002082

Feldman, Naomi E., and Joel Slemrod. 2009. War and Taxation: When Does Patriotism Overcome the Free-Rider Impulse. In The New Fiscal Sociology: Taxation in Comparative and Historical Perspective, ed. Isaac William Martin, Ajay K. Mehrotra, and Monica Prasad, 138-154. Cambridge: Cambridge University Press. https://www.google.com/books?hl=sv\&lr=\&id=vdzgZwhu FZUC\&oi=fnd\&pg=PAl $38 \& d q=$ Feldman+\%26+Slemrod\&ots=IkrDERlxsJ\& sig=MZBjiUfEO42SyBGY0069hklIaFc 
Firth, Raymond. 1959. Social Change in Tikopia. London and New York: George Allen \& Unwin.

Fortin, Bernard, Guy Lacroix, and Marie-Claire Villeval. 2007. Tax Evasion and Social Interactions. Journal of Public Economics 91 (11-12): 2089-2012. http://www.sciencedirect.com/science/article/pii/S0047272707000497

Frey, Bruno S., and Benno Torgler. 2007. Tax Morale and Conditional Cooperation. Journal of Comparative Economics 35: 136-159. http://www. sciencedirect.com/science/article/pii/S0147596706000849

Frykman, Jonas, and Kjell Hansen. 2009. Welfare State, Health and Local Culture. http://tryggvar.se/publikationer/welfare_state_health_and_local_culture.pdf

Gavanas, Anna, and Catarina Calleman. 2013. Rena Hem På Smutsiga Villkor?: Hushållstjänster, Migration Och Globalisering. Göteborg: Makadam förlag.

Geertz, Clifford. 1973. The Interpretation of Cultures. New York: Basic Books.

Godbout, Jacques, and Alain Caille. 1998. The World of the Gift. Montreal: McGillQueen's University Press.

Gordon, James P.F. 1989. Individual Morality and Reputation Costs as Deterrents to Tax Evasion. European Economic Review 33: 797-805. http://www.sciencedirect.com/science/article/pii/0014292189900263

Gracia, Louise, and Lynne Oats. 2012. Boundary Work and Tax Regulation: A Bourdieusian View. Accounting, Organizations and Society 37 (5): 304-321. https://doi.org/10.1016/j.aos.2012.03.004

Graeber, David. 2001. Toward an Anthropological Theory of Value: The False Coin of Our Own Dreams. New York: Palgrave Macmillan.

Graham, Mark. 2002. Emotional Bureaucracies: Emotions Civil Servants, and Immigrants in the Swedish Welfare State. Ethos 30 (3): 199-226. https://doi. org/10.1525/eth.2002.30.3.199

Gregory, C.A. 1994. Exchange and Reciprocity. Companion Encyclopaedia of Anthropology: 911-939.

Gribnau, H. 2013. Legal Certainty: A Matter of Principle. In Retroactivity of Tax Legislation, ed. Hans Gribnau and Melvin Pauwels, 69-95. Amsterdam: EATLP.

Gribnau, Hans. 2015. Taxation, Reciprocity and Communicative Regulation. Tilburg Law Review 20: 191-212. http://booksandjournals.brillonline.com/ content/journals/10.1163/22112596-02002009

Guala, Francesco. 2012. Reciprocity: Weak or Strong? What Punishment Experiments Do (and Do Not) Demonstrate. Behavioral and Brain Sciences 35 (1): 1-15. https://doi.org/10.1017/S0140525X11000069

Gudeman, Stephen. 2001. The Anthropology of Economy: Community, Market, and Culture. Oxford: Blackwell Publishers.

Hadenius, Axel. 1985. Citizens Strike a Balance: Discontent with Taxes, Content with Spending. Journal of Public Policy 5 (3): 349-363. http://journals.cambridge.org/abstract_S0143814X00003159 
Hanousek, J., and F. Palda. 2004. Quality of Government Services and the Civic Duty to Pay Taxes in the Czech and Slovak Republics, and Other Transition Countries. Kyklos 57 (2): 237-252. http://onlinelibrary.wiley.com/doi/ $10.1111 / \mathrm{j} .0023-5962.2004 .00252 . \mathrm{x} /$ full

Hansson, Ingemar. 2011. Företagets inställning till skatter är en styrelsefråga. Dagens Industri 18 (5): 2011.

Hart, Keith. 2007. Marcel Mauss: In Pursuit of the Whole. A Review Essay. Comparative Studies in Society and History 49 (2): 473-485.

Herrmann, Gretchen M. 1997. Gift or Commodity: What Changes Hands in the US Garage Sale? American Ethnologist 24 (4): 910-930.

High, Holly, and Clare Hall. 2012. Re-Reading the Potlatch in a Time of Crisis: Debt and the Distinctions That Matter 1. Social Anthropology 20 (4): 363-379. https://doi.org/10.1111/j.1469-8676.2012.00218.x

Holmberg, Sören, and Nora Oleskog Tryggvason. 2014. Svenska folkets bedömning av offentliga myndigheters verksambet (Report 11). Göteborg: SOM-institutet.

Inglehart, Ronald. 2006. Inglehart-Welzel Cultural Map of the World. World Values Survey. https://scholar.google.se/scholar?q=Inglehart-Welzel+Cultura $1+\mathrm{Map}+$ of + the + World \&btnG $=\& \mathrm{hl}=$ sv\&as_sdt $=0 \% 2 \mathrm{C} 5$

Jacobsson, Kerstin. 2006. Durkheims moralsociologi och välfärdsstaten. http:// www.score.su.se/polopoly_fs/1.26584.1320939799!/20063.pdf

Kirchler, Erich. 2007. The Economic Psychology of Tax Behaviour. Cambridge: Cambridge University Press. https://www.google.com/books?hl=sv\&lr=\&id =dh0qhqTOtb0C\&oi=fnd\&pg=PR7\&dq=erich+kirchler\&ots=nolZAAWIKd \&sig=HsX_aai3HBSgF0_xX4cKtKoULIM

Komter, Aafke E. 1996. The Gift: An Interdisciplinary Perspective. Amsterdam: Amsterdam University Press. https://www.google.com/books?hl=sv\&lr=\&id $=\mathrm{o} 7 \mathrm{wq} 4 \mathrm{oO} 2 \mathrm{~B} 0 Y \mathrm{YC} \& \mathrm{oi}=$ fnd $\& p g=\mathrm{PAl} \& \mathrm{dq}=$ the + gift + komter $+1996 \&$ ots $=$ rr0 $\mathrm{d}$ 8yW9pn\&sig=rF8xKWNVD5BJSJtll lbf0YgUGLQ

. 2014. Idealized Versus Real-Life Reciprocity: How to Strike the Balance? Netherlands Journal of Legal Philosophy 43 (2): 158-171.

Kornhauser, Marjorie E. 2007. Tax Morale Approach to Compliance: Recommendations for the IRS, A. Florida Tax Review 8 (6): 599-634. http:// heinonlinebackup.com/hol-cgi-bin/get_pdf.cgi?handle=hein.journals / ftaxr8\&section $=27$

L'Estoile, Benoit De. 2014. 'Money Is Good, but a Friend Is Better'. Uncertainty, Orientation to the Future and 'The Economy'. Current Anthropology 55 (S9): 62-73. http://halshs.archives-ouvertes.fr/hal-00935026/

Ledeneva, A.V. 1998. Russia's Economy of Favours: Blat, Networking, and Informal Exchange. Cambridge: Cambridge University Press.

Lévi-Strauss, Claude. 1966. The Savage Mind. Chicago: University of Chicago Press. http://www.citeulike.org/group/716/article/197326

Lewin, Leif. 2008. Samling Kring Folkhemmet. In Mellan Folkhem Och Europa, ed. Li Bennich-Björkman and Paula Blomqvist, 20-39. Liber. 
Lindbeck, Assar, Sten Nyberg, and Jörgen W. Weibull. 1999. Social Norms and Economic Incentives in the Welfare State. Quarterly Journal of Economics CXIV (1): 1-35. http://www.jstor.org/stable/2586946

Lodin, Sven-Olof. 2007. Några Kvalitetskrav På En God Skattelagstiftning. Skattenytt 2007 (9): 477-490.

MacCormack, Geoffrey. 1976. Reciprocity. Man 11 (1): 89-103. http://www. jstor.org/stable/2800390

Malinowski, Bronislaw. 1966 [1922]. Argonauts of the Western Pacific. London: Routledge \& Kegan Paul. https://scholar.google.se/scholar?hl=sv\&q=malino wski+1922\&btnG=\#5

Martin, Isaac William, Ajay K. Mehrotra, and Monica Prasad. 2009. The New Fiscal Sociology: Taxation in Comparative and Historical Perspective. Cambridge: Cambridge University Press. http://www.cambridge.org/gb/knowledge/ isbn/item2427351/?site_locale=en_GB

Maurer, Bill. 2016. Foreword: Puzzles and Pathways. In The Gift: Expanded Edition/Marcel Mauss. Selected, Annotated and Translated by Jane I. Guyer, ix-xvii. Chicago: HAU Books.

Mauss, Marcel. 2002 [1990]. The Gift. London: Routledge.

- 2016. The Gift: Expanded Edition/Marcel Mauss. Selected, Annotated and Translated by Jane I. Guyer. Chicago: Hau Books.

Mulligan, Emer, and Lynne Oats. 2015. Tax Professionals at Work in Silicon Valley. Accounting, Organizations and Society 52: 63-76.

Musgrave, R.A. 1992. Schumpeter's Crisis of the Tax State: An Essay in Fiscal Sociology. Journal of Evolutionary Economics 2 (2): 89-113. https://doi. org/10.1007/BF01193535

Narotzky, Susana, and Paz Moreno. 2002. Reciprocity's Dark Side: Negative Reciprocity, Morality and Social Reproduction. Anthropological Theory 2 (3): 281-305.

Oats, Lynne, and Diana Onu. 2016. Tax Talk: An Exploration of Online Discussions Among Taxpayers. Journal of Business Ethics: 1-14. https://doi. org/10.1007/s10551-016-3032-y

Offer, Avner. 1997. Between the Gift and the Market: The Economy of Regard. The Economic History Review 50 (3): 450-476.

Ortner, Sheryl B. 2003. New Jersey Dreaming: Capital, Culture, and the Class of 58. Durham, NC: Duke University Press.

Pardo, Italo. 1996. Managing Existence in Naples: Morality, Action, and Structure. Cambridge: Cambridge University Press.

Polanyi, Karl. 2001 [1944]. The Great Transformation: The Political and Economic Origins of Our Time. Boston: Beacon Press. https://scholar.google.se/scholar ?hl=sv\&q=polanyi\&btnG=\#l

Pommerehne, Werner W., Albert Hart, and Bruno S. Frey. 1994. Tax Morale, Tax Evasion and the Choice of Policy Instruments in Different Political Systems. 
Public Finance 49 (Supplement): 52-69. https://ideas.repec.org/a/pfi/pubfin/v49y1994isupplementp52-69.html

Portes, Alejandro, Manuel Castells, and Lauren A. Benton. 1989. The Informal Economy: Studies in Advanced and Less Developed Countries. Baltimore, MD: Johns Hopkins University Press.

Rabin, Matthew. 1998. Psychology and Economics. Journal of Economic Literature 36: 11-46. http://www.jstor.org/stable/2564950

Rawlings, Gregory, and Valerie Braithwaite. 2003. Voices for Change: Australian Perspectives on Tax Administration. Australian Journal of Social Issues (Australian Council of Social Service) 38 (3): 263-268.

Rosenberg, Göran. 2013. Sweden: The Reluctant Nation. In Populist Fantasies: European Revolts in Context, ed. Catherine Fieschi, Marley Morris, and Lila Caballero, 151-209. Counterpoint. http://counterpoint.uk.com/wp-content/ uploads $/ 2013 / 10 /$ Populist-Fantasies-European-revolts-in-context.pdf\#page $=82$

Rothstein, Bo. 1992. Den Korporativa Staten: Intresseorganisationer Och Statsförvaltning I Svensk Politik. Stockholm: Norstedts.

Sahlins, Marshall D. 1972. Stone Age Economics. London: Routledge.

San Juan, Eric A. 2013. Cultural Jurisprudence. Asian Pacific Law \& Policy Journal 15 (1). https://litigation-essentials.lexisnexis.com/webcd/app?action $=$ Document Display\& crawlid $=1 \&$ doctype $=$ cite $\&$ docid $=15+$ Asian - Pacific + L. $+\%$ $26+$ Pol'y + J. $+1 \&$ srctype $=$ smi \&srcid $=3$ B $15 \& k e y=6 d 4241831616 c 4765 b 24 \mathrm{e} 2$ $0143 \mathrm{f} 893 \mathrm{~b} 0$

Schneider, Friedrich, and Dominik H. Enste. 2002. The Shadow Economy: An International Survey. Cambridge: Cambridge University Press. http://www. google.com/books?hl=sv\&lr=\&id=tMzmHgd2qNcC\&oi=fnd\&pg=PR7\&ots $=$ EEf4vbyyTM\&sig=bDIlmRotakrfnLn30AAUtPUwmWE

Schnellenbach, Jan. 2010. Vertical and Horizontal Reciprocity in a Theory of Taxpayer Compliance. In Developing Alternative Frameworks for Explaining Tax Compliance, ed. James Alm, Juan Martinez-Vasquez, and Benno Torgler, 56-73. New York, NY: Routledge International Studies in Money and Banking. Schumpeter, Joseph A. 1954. The Crisis of the Tax State. International Economic Papers 4: 5-38.

Skatteverket. 2007. Svartköp och svartjobb i Sverige. Del 2: Möjliga åtgärder mot svartarbete och bidragsfusk. Solna: Skatteverket.

- 2008. Mätning av skatteverkets effekter på dess omgivning. Solna: Skatteverket.

—. 2012. Medborgarnas synpunkter på skattesystemet, skattefusket och Skatteverkets kontroll. Solna: Skatteverket.

- 2014. Verksambetsplan för Skatteverket. Solna: Skatteverket.

Slater, Don. 2002. From Calculation to Alienation: Disentangling Economic Abstractions. Economy and Society 31 (2): 234. Routledge. http://search. ebscohost.com/login.$a s p x$ ? direct $=$ true $\& d b=b t h \& A N=6446266 \&$ site $=$ ehost-live

Slemrod, Joel B. 1992. Why People Pay Taxes: Tax Compliance and Enforcement. Edited by Joel B. Slemrod. Ann Arbor: University of Michigan Press. 
2007. Cheating Ourselves: The Economics of Tax Evasion. The Journal of Economic Perspectives 21 (1): 25-48. http://www.jstor.org/stable/30033700

Smith, K.W. 1992. Reciprocity and Fairness: Positive Incentives for Tax Compliance. In Why People Pay Taxes, Tax Compliance and Enforcement, ed. Joel B. Slemrod, 223-250. Ann Arbor: University of Michigan Press.

Spicer, Michael W., and S.B. Lundstedt. 1976. Understanding Tax Evasion. Public Finance 30 (4). https://works.bepress.com/michael_spicer/?paginate= 1 \&page $=4 \&$ page $\_$size $=25$

Steinmo, Sven. 1996. Taxation and Democracy: Swedish, British, and American Approaches to Financing the Modern State. Yale University Press.

Steinmo, S. 2002. Globalization and Taxation Challenges to the Swedish Welfare State. Comparative Political Studies 35 (7): 839-862. http://cps.sagepub.com/ content $/ 35 / 7 / 839$.short

Stridh, Anders, and Lennart Wittberg. 2015. Frain Fruktad Skattefogde till Omtyckt Servicemyndighet. Solna: Skatteverket.

Svallfors, Stefan. 1995. The End of Class Politics? Structural Cleavages and Attitudes to Swedish Welfare Policies. Acta Sociologica 38 (1): 53-74.

Swedberg, Richard. 2003. Principles of Economic Sociology. Princeton, NJ: Princeton University Press.

Thomassen, Bjorn. 2015. Begging Rome: Norms at the Margins, Norms of the in-Between. Critique of Anthropology. http://coa.sagepub.com/content/ $35 / 1 / 94$.short

Westerman, Pauline. 2014. Reciprocity: A Fragile Equilibrium. Netherlands Journal of Legal Philosophy 2 (43): 172-184.

Widlok, Thomas. 2013. Allowing Others to Take What is Valued. HAU: Journal of Ethnographic Theory 3 (2): 11-31.

Williams, Colin C., and Jan Windebank. 1998. Informal Employment in the Advanced Economies: Implications for Work and Welfare. London: Routledge.

Open Access This chapter is licensed under the terms of the Creative Commons Attribution 4.0 International License (http://creativecommons.org/licenses/ by $/ 4.0 /$ ), which permits use, sharing, adaptation, distribution and reproduction in any medium or format, as long as you give appropriate credit to the original author(s) and the source, provide a link to the Creative Commons license and indicate if changes were made.

The images or other third party material in this chapter are included in the chapter's Creative Commons license, unless indicated otherwise in a credit line to the material. If material is not included in the chapter's Creative Commons license and your intended use is not permitted by statutory regulation or exceeds the permitted use, you will need to obtain permission directly from the copyright holder.

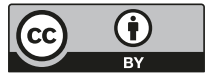

